\title{
ENTRE A MÃO E A CABEÇA, 0 FAZER E 0 PENSAR: EIS $O$ ARTÍFICE
}

\author{
Por Ana Cristina Batista-dos-Santos \\ Professora do Departamento de Agrotecnologia e Ciências Sociais, Universidade Federal Rural do Semi-Árido - Mossoró - RN, Brasil \\ Miguel Eduardo Moreno Añez \\ Professor do Centro de Ciências Sociais Aplicadas, Universidade Federal do Rio Grande do Norte - Natal - RN, Brasil
}

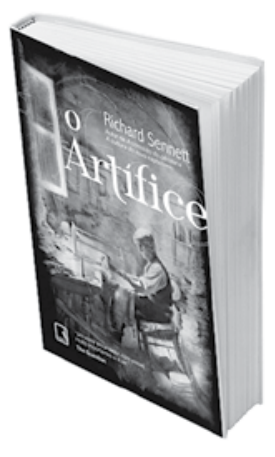

\section{O ARTÍFICE}

De Richard Sennett. Rio de Janeiro: Record, 2009. 360 p.

Desde o título que deu à obra, Sennett expressa, através da força de uma "figura tipo" - O Artífice - a ideia dominante em todo o livro: a da atividade material, prática, artesanal, como a unidade possível entre diversos pares ambíguos, tais como: mente versus corpo, pensamento versus ação, concepção versus execução, teoria versus prática, homo faber versus animal laborens. Sobre esse último par conflitante, o autor destaca, logo de início, sua divergência em relação a sua outrora professora, a filósofa contemporânea Hannah Arendt, de quem discorda quanto à suposta superioridade, por ela imputada, do homo faber, aquele que cria a vida através do trabalho, sobre o animal laborens, que estaria condenado à rotina do trabalho braçal, tal qual um animal de carga. Sennett advoga que essa distinção é falsa e como que redime o animal laborens de sua inferioridade, defendendo a tese de ser este capaz de pensar. O autor "tece" as intrigantes páginas de seu livro ratificando continuamente sua ideia original, isto é, da atividade material como síntese daquelas ambiguidades; para ele, sentimento e pensamento são tornados possíveis ao homem por meio do fazer, pela mediação que a atividade material oferece. Nessa perspectiva, Sennett propõe e persegue dois objetivos em $O$ Artifice: (i) explicar o engajamento prático, mas não necessariamente instrumental, das pessoas; (ii) mostrar os prejuízos para a "cabeça humana" quando da separação entre mão e cabeça, técnica e ciência, arte e artesanato.
O eixo da obra de Sennett está no tripé: artífice, artesanato e habilidade artesanal. Para falar do artífice, figura mestra da sua obra, Sennett volta à Grécia antiga, recorrendo às virtudes do "deus dos artífices", Hefesto, repleto de habilidades produtoras de civilização, uma vez que o artesanato teria tirado as pessoas do isolamento, introduzindo-as no contexto de comunidade; e o contrapõe a Pandora com sua convidativa caixa, promotora, porém, de sofrimento e destruição. Do artífice, Sennett destaca os importantes elos entre autoridade e habilidades, no contexto das oficinas medievais; as contraditórias relações entre o artífice e as máquinas; e, finalmente, o alto nível de intimidade entre o artífice e os materiais que utiliza, discorrendo a respeito de uma espé- 
cie de consciência material que cada artífice teria altamente desenvolvida.

Ao tratar do artesanato, Sennett é mais contundente quanto à ideia do forte vínculo entre a mão e a cabeça e com a própria evolução cultural. Lança luzes sobre peculiaridades da mão, como o ato de pegar, o qual estaria permeado de voluntariedade, ato que teria tornado possível o surgimento do homo faber, pois, uma vez que o homem tornou-se capaz de segurar as coisas, pôde trabalhar com elas. O autor situa a capacidade de tolerar a bagunça, a incerteza e mesmo o erro como marca distintiva do trabalho artesanal, além de destacar que o desenvolvimento das habilidades sofisticadas ligadas ao trabalho artesanal demanda do artífice uma capacidade para se envolver em atividades repetitivas, as quais aprimorariam a técnica.

Quanto ao tema da habilidade artesanal, Sennett estabelece uma relação direta entre as habilidades do artífice e a esfera do desejo, argumentando que há nele permanentemente uma busca pela qualidade, um querer fazer bem o trabalho, donde conclui que a motivação é mais importante que o talento no tocante ao desenvolvimento das habilidades artesanais. Destaca, ainda, duas necessidades importantes para o desenvolvimento das habilidades de um artífice: o aprendizado lento e o hábito.
Sennett conclui sua obra apresentando a corrente filosófica em que ela esteve ancorada, ou, visto de outra forma, a perspectiva filosófica que $O$ Artifice procurou justificar ou comprovar com minuciosas exemplificações: o pragmatismo. Aponta o conceito de experiência como síntese do pragmatismo sob duas concepções: a da experiência no tocante aos aspectos emocionais, íntimos, sensíveis; e a da experiência em sua faceta mais exterior, que requer mais habilidade que sensibilidade, que lida com o exterior, dimensão que sua obra privilegiou.

Apesar de ampla, a obra O Artífice, quando vista em conjunto, parece insistir, através de uma fartura de detalhes e exemplos, em um único e mesmo ponto: a precedência da prática, da ação, do fazer, do corpo, da mão, do animal laborens. Assim, como que Sennett escorrega no mesmo tipo de raciocínio de sua professora Arendt, que acusara. Para o autor, parece haver uma superioridade do animal laborens, e não uma unidade dialética do mesmo com o homo faber.

Envolvido em um exercício do tipo "o que vem primeiro?" (a mão ou a cabeça? o fazer ou o pensar? a teoria ou a prática?), o texto como que passa ao largo de questões como a relação do tempo, do aprendizado, do hábito, da qualidade, da incerteza e do erro do trabalho do artífice, no contexto do mundo do trabalho contemporâneo. Embora reserve algumas poucas linhas para tratar de aspectos institucionais que por vezes limitam o fazer do artífice, no geral, escapa à obra uma discussão sobre dimensões interferentes na relação do homem com o seu fazer. Sennett silencia sobre as condições sociais, históricas, econômicas e políticas de produção dos inúmeros artífices que cita, tema que privilegiou em outras de suas obras, igualmente instigantes, como A Corrosão do Caráter e A Cultura do Novo Capitalismo. Diferentemente de O Artífice, nessas obras, o que Sennett destaca e critica são os elementos de mediação que se interpõem ao homem em sua relação com o trabalho. Assim, na riqueza de detalhes, de pormenores e de belas exemplificações contidas no livro, assiste-se também a uma escassez, um vazio, um silêncio sobre a relação dialética do artífice no mundo. Ao focar na intersecção entre a mão e a cabeça, Sennett parece "deixar às escuras" os contextos em que essa mão, essa cabeça, esse corpo, esse artífice, esse trabalhador, enfim, esse homem ocupa no mundo.

Certamente, estas e outras questões instigariam sua mestra já falecida a continuar o debate. Da mesma forma, a obra é um convite instigante à reflexão, razão suficiente para que seja lida e fartamente discutida. 